\title{
Working Together towards a Child-Abuse-Free Society: From Imagination to Reality
}

\author{
Mohajer A. Hameed \\ Intergenerational Health Research Group, Murdoch Children's Research Institute, Melbourne, Australia \\ Email: mohajer.hameed@mcri.edu.au
}

How to cite this paper: Hameed, M. A. (2021). Working Together towards a ChildAbuse-Free Society: From Imagination to Reality. Open Journal of Social Sciences, 9, 416-433.

https://doi.org/10.4236/jss.2021.98029

Received: July 27, 2021

Accepted: August 24, 2021

Published: August 27, 2021

Copyright $\odot 2021$ by author(s) and Scientific Research Publishing Inc. This work is licensed under the Creative Commons Attribution International License (CC BY 4.0).

http://creativecommons.org/licenses/by/4.0/

\begin{abstract}
The aim of this paper is to provide an overview of key research insights about child abuse and neglect, since the early 1960s, with an emphasis on prevention science and practices. A narrative review of the literature was selected to highlight the overall pattern of research findings related to the prevention of child abuse and neglect. This paper takes an ambitious goal of exploring whether working together towards a society free of child abuse is pure imagination, a possibility, a reality, or something else. The World report on violence and health recommends a public health approach within an ecological framework that emphasises social-justice methods as promising universal prevention strategies to end child abuse and neglect. In addition, collective and coordinated efforts of researchers, practitioners, policy makers, parents and caregivers have the potential to change the current situation, and substantially contribute to stronger futures where all children live within safer families and societies, free from abuse and neglect. However, many challenges exist in the current global climate of great social, economic and health inequalities. Nevertheless, this paper is motivated by a strong hope that it is possible to globally eradicate child abuse and neglect and emphasise that every child in the world has the right to live free from abuse and neglect, and to feel safe, respected, valued and treated with dignity in public and family life.
\end{abstract}

\section{Keywords}

Child Abuse and Neglect, Society, Prevention Science and Practices, Rights and Social Justice

\section{Introduction}

Historical literature reviews on the medical and psychological care of children recognised the issue of deliberate parental harm to children (e.g., Knight, 1986; Koenen \& Thompson Jr., 2008; Lynch, 1985; Modanlou, 2015; Thomas Jr., 1971). 
Such research suggests that before recorded human history, deliberate parental acts of harm, ranging from neglect, abuse to killing children, were committed in every society and across all cultures, yet the rationale and justification for, and social reactions to, the child and the parent varied (Lynch, 1985; Qiao \& Chan, 2005; Pfohl, 1977). Child abuse and neglect by biological parents and other caregivers continue to exist today in every society of the world, but not in every family. This is a worldwide concern occurring in an epidemic proportion across all societies, racial and ethnic groups worldwide (WHO, 2016b).

It is generally considered that non-accidental parental harm to children has existed since the first parent-child interaction. The first surviving medical treatise in paediatrics is considered Rhazes' Practica Peurorum. Rhaze was a Persian physician (865-925 AD) who extensively practised in the harems of Baghdad (which is where women brought their children for medical and psychiatric/psychological treatment) (Daghestani, 1997; Radbill, 1971; Tubbs, Shoja, Loukas, \& Oakes, 2007). Although the Practica Peurorum was written in approximately 900AD, Rhaze cites much earlier texts on the medical, psychiatric and psychological care of children, including the recognition of deliberate parental harm to children in the works of Soranus, Oribasius (325-403 AD), Aetius (502-575 AD), Paulus (625-690 AD), as well as in early medical writers of India, Charaka and Susruta. However, it has been reported that Rhaze was the first who "siphoned off paediatrics into a monograph of its own” (Radbill, 1971: p. 370).

Nevertheless, coordinated efforts towards the medicalisation and criminalisation of child abuse and neglect were initiated only approximately in early 1960s, after the publication of "The battered child syndrome" in the Journal of the American Medical Association (Kempe, Silverman, Steele, Droegemueller, \& Silver, 1962). In the following year, Griffiths and Moynihan (1963) (orthopaedic surgeons) published case studies related to Kempe and Colleagues' (1962) research, drawing attention to "babies brought to hospital with unexplained swellings in the region of the ends of long bones who are in fact victims of unsuspected trauma which is often brutal and which has usually been inflicted by a parent" (p. 1558). Lynch (1985) and Pfohl (1977) provide detailed historical reviews and critical analyses of the social forces that gave rise to the understanding of child abuse as a "disease" and a public-health concern.

Since the early 1960s, thousands of studies have been published across the globe, examining various domains of child abuse, ranging from neglect to filicide. The aim of this paper is to narratively review and highlight key insights related to child abuse and neglect since the early 1960s, particularly about prevention science and practices. The paper represents a genuine attempt to open up the possibility of having a united voice, strategy and actions at local, national, and international communities to end child abuse and neglect. The paper is motivated by a strong hope that child abuse and neglect can be eradicated globally.

\section{Who Is a Child and What Is Childhood?}

Perspectives about who is a child and what is the meaning of childhood, may 
shape how societies, parents and other caregivers interact with children in everyday life (Morrow, 2011). There are many histories of childhood and various conceptualisations of the child that have evolved throughout human history (Marten, 2018), yet this topic is beyond the scope of this paper. Nevertheless, for the purpose of this paper, a child "means every human being below the age of eighteen years unless, under the law applicable to the child, majority is attained earlier" (United Nations Convention on the Rights of the Child, UNICEF, 1999). From a human rights perspective, children are entitled to be treated with respect, dignity and protected from any form of abuse and harm-perpetrated by society (e.g. systemic abuse such as inequities, armed conflicts, poverty) and/or parents/ caregivers (e.g. child abuse).

\section{Child Abuse across the Globe: Epidemiology}

From the initial conceptualisation of child abuse and neglect as a medicolegal issue in the 1960s, it has been clear that the "extent of the problem is not easy to estimate [and] convictions for such offences are only the tip of the iceberg in relation to the total of maltreated children" (Fleming, 1967: p. 421). Generally, earlier researchers recognised clearly that available statistics are unreliable and the "true incidence is difficult to establish" (Bell, 1973: p. 223). Despite the difficulties in operational definitions and estimating the extent of the problem, various national and international attempts have been made to estimate national and global incidence of child abuse and neglect.

For example, since early 1990s, the International Society for Prevention of Child Abuse and Neglect (ISPCAN) has systematically estimated incidence across 30 to more than 75 countries worldwide (Daro et al., 1992; WHO, 2016b). The global estimate of presumed child abuse and neglect mortality for infants younger than five years of age during the period 1985-1990 was 13 - 20 per 100,000 live births (data based on 64 countries) (Belsey, 1993). More broadly, a systematic synthesis of data on past-year prevalence of any form of violence against children from approximately half of the countries in the world (96 countries) found that "over one billion children ages two to 17 years have experienced violence in the past year" (Hillis, Mercy, Amobi, \& Kress, 2016: p. 10).

More specifically, utilising meta-analytic techniques, Stoltenborgh, BakermansKranenburg, Alink and van Ijzendoorn (2015) estimated the global prevalence derived from 244 publications and 551 prevalence rates for various types of child abuse and neglect (e.g. 127/1000 for sexual abuse, 226/1000 for physical abuse, $363 / 1000$ for emotional abuse), and later, Prevoo, Stoltenborgh, Alink, Bakermans-Kranenburg and Ijzendoorn (2017) provided an updated analysis accounting for methodological moderators in prevalence studies. Despite the difficulties in estimating the true global prevalence of child abuse and neglect, the general consensus is that child abuse and neglect is a global public-health problem occurring at an epidemic level across all societies, racial and ethnic groups worldwide. Both national and global estimates are likely to provide an underestima- 
tion of the true numbers, representing only the "tip of the iceberg" (Belsey, 1993: p. 75).

International organisations such as the ISPCAN, the World Health Organization (WHO), the United Nations, and SOS Children's Villages International, have clearly identified the global spread of this problem and have strongly advocated for the protection of children who continue to experience various forms of violence, neglect and abuse perpetrated by parents and/or societies (Daro et al., 1992; Krug, Mercy, Dahlberg, \& Zwi, 2002; Ullmann \& Hilweg, 1999). National and global reports find that rates of child abuse and neglect perpetrated by biological parents have risen to alarming levels (Lutzker \& Newman, 1986). In addition, at a societal level, "the situation of children in many parts of the world remains critical as a result of inadequate social conditions, natural disasters, armed conflicts, exploitation, illiteracy, hunger and disability" (United Nations Convention on the Rights of the Child, UNICEF, 1999).

In response to the increasing number of children impacted by adverse experiences including abuse, neglect, intergenerational trauma, social and health inequities, substantial prevention initiatives, public policies, programmes and studies have been developed, implemented, evaluated and published worldwide. However, prevention efforts at the local, national, and international community levels depends greatly on theoretical models and understanding of risk and protective factors.

\section{Theoretical Models of Child Abuse and Neglect}

Why some parents neglect, abuse or even kill their children has been a central question of the past and continues to be so in the present. As an emergent medicolegal problem during the 1960s (Fleming, 1967), it was generally considered that there are four categories of parents who deliberately harm their children. These were parents presenting with: 1) a violent cultural background; 2) aggressive or schizoid psychopathy; 3 ) irritability, emotional lability with episodic depressive illness; and 4) psychopathy (Fairburn \& Hunt, 1964). Other factors and characteristics such as an "irresponsible father, drink, moral danger, mental deficiency of a parent, mental deficiency of the child, unwanted child" (Ferguson, 1955: p. 184) were also identified as contributing factors to child abuse and neglect. The focus on parental social and health characteristics and family-stress factors was soon shifted to the role of society in inflicting harm on families and children: societal abuse was manifested "by the statistics on infant mortality, hunger and malnutrition, poverty, inadequate medical care, poor education, and officially sanctioned physical abuse in schools, correctional institutions, child care facilities, and juvenile courts" (Gil, 1970).

Subsequently, various theoretical/aetiological paradigms and frameworks emerged as research on child abuse and neglect progressed. Table 1 summarises a selection of major theoretical models that have emerged since early 1960s which have implications for prevention science and practices. Overall, each theoretical 
model posits that particular risk factors elicit or contribute to the occurrence of child abuse and neglect. In this context, these risk factors are defined as variables that precede (antecedents or precursors) and are associated with child abuse and neglect.

Table 1. Major aetiological paradigms of child abuse and neglect and implications for prevention science and practices.

\begin{tabular}{|c|c|c|c|c|c|}
\hline $\begin{array}{l}\text { Major theoretical } \\
\text { models (main } \\
\text { period) }\end{array}$ & Related theories & $\begin{array}{l}\text { Point of } \\
\text { dis-order }\end{array}$ & $\begin{array}{l}\text { Examples of "risk" } \\
\text { factors }\end{array}$ & $\begin{array}{l}\text { Examples of empirical } \\
\text { support }\end{array}$ & $\begin{array}{l}\text { Implications for prevention } \\
\text { science and practice }\end{array}$ \\
\hline $\begin{array}{l}\text { Psychiatric \& } \\
\text { psychological } \\
(1960 \text { s) }\end{array}$ & $\begin{array}{l}\text { Medical; parental } \\
\text { psychopathology; } \\
\text { intergenerational } \\
\text { transmission of child } \\
\text { abuse; psychodynamic } \\
\text { theories including } \\
\text { attachment, social } \\
\text { learning, behavioural and } \\
\text { cognitive theories }\end{array}$ & Parent & $\begin{array}{l}\text { Parental health } \\
\text { characteristics including } \\
\text { mental ill-health, family } \\
\text { violence, alcohol-other } \\
\text { drugs misuse; life crisis } \\
\text { and stressors; } \\
\text { parent-child role reversal }\end{array}$ & $\begin{array}{l}\text { (Fairburn \& Hunt, 1964; } \\
\text { Ferguson, 1955; Fitch \& } \\
\text { Papantonio, 1983; } \\
\text { Friedrich \& Wheeler, 1982) }\end{array}$ & $\begin{array}{l}\text { - Selective and indicative } \\
\text { prevention programs } \\
\text { - Individualised adult } \\
\text { psycho-therapeutics } \\
\text { - Family preservation services } \\
\text { - Home visitation }\end{array}$ \\
\hline $\begin{array}{l}\text { Child-initiated } \\
\text { abuse (1960s) }\end{array}$ & $\begin{array}{l}\text { Goodness-of-fit } \\
\text { (child temperament and } \\
\text { parent sensitivity- } \\
\text { responsiveness); child } \\
\text { behaviour including } \\
\text { crying behaviour }\end{array}$ & Child & $\begin{array}{l}\text { Child-characteristics } \\
\text { including younger age, } \\
\text { misbehaviour, conduct } \\
\text { and related issues, } \\
\text { disabilities (special } \\
\text { needs), difficult child } \\
\text { temperament }\end{array}$ & $\begin{array}{l}\text { (Ammerman, Van Hasselt, } \\
\text { \& Hersen, 1988; Chess \& } \\
\text { Thomas, 1991; Kapitanoff, } \\
\text { Lutzker, \& Bigelow, 2000; } \\
\text { Milowe, Lourie, \& Parrott, } \\
\text { 1964; White, Benedict, } \\
\text { Wulff, \& Kelley, 1987) }\end{array}$ & $\begin{array}{l}\text { - Parent education and } \\
\text { training programmes } \\
\text { - Family support services } \\
\text { - Home visitation } \\
\text { - Child-focused family } \\
\text { therapies }\end{array}$ \\
\hline $\begin{array}{l}\text { Sociological \& } \\
\text { environmental } \\
(1970 \text { s })\end{array}$ & $\begin{array}{l}\text { Social systems theory; } \\
\text { culture, norms, traditions, } \\
\text { and customs }\end{array}$ & $\begin{array}{l}\text { Societal } \\
\text { (situational/ } \\
\text { contextual } \\
\text { factors) }\end{array}$ & $\begin{array}{l}\text { Poverty; social } \\
\text { disadvantaged } \\
\text { neighbourhoods; } \\
\text { unemployment; social } \\
\text { isolation; stressful and } \\
\text { "toxic" social } \\
\text { environments; lack of } \\
\text { social support systems; } \\
\text { cultural acceptance of } \\
\text { violence against children }\end{array}$ & $\begin{array}{l}\text { (Drake \& Pandey, 1996; } \\
\text { Garbarino, 1995; Gil, 1969; } \\
\text { Slack, Holl, McDaniel, Yoo, } \\
\text { \& Bolger, 2004; Wolock, } \\
\text { 1984) }\end{array}$ & $\begin{array}{l}\text { - Social-justice approaches } \\
\text { - Systemic interventions } \\
\text { - Population-level approaches } \\
\text { - Community-based } \\
\text { initiatives } \\
\text { - Mass media and social } \\
\text { marketing approaches } \\
\text { - Economical and material } \\
\text { support }\end{array}$ \\
\hline $\begin{array}{l}\text { Developmental- } \\
\text { Ecological- } \\
\text { transactional } \\
(1980 \text { s) }\end{array}$ & $\begin{array}{l}\text { Developmental } \\
\text { psychopathology; } \\
\text { socioecological theory }\end{array}$ & $\begin{array}{l}\text { Parent-child- } \\
\text { society }\end{array}$ & $\begin{array}{l}\text { Family and societal } \\
\text { characteristics including } \\
\text { multiple cumulative risk } \\
\text { factors }\end{array}$ & $\begin{array}{l}\text { (Asen, George, Piper, \& } \\
\text { Stevens, 1989; Belsky, 1993; } \\
\text { Cicchetti \& Lynch, 1993; } \\
\text { Wulczyn et al., 2010) }\end{array}$ & $\begin{array}{l}\text { - Public-health models and } \\
\text { primary prevention } \\
\text { - Social policies and } \\
\text { legislations } \\
\text { - Neighbourhood-based } \\
\text { interventions } \\
\text { - Systems approach in } \\
\text { child-protection } \\
\text { intervention/prevention }\end{array}$ \\
\hline $\begin{array}{l}\text { Bio-psycho- } \\
\text { socio-cultural } \\
\text { (since 1990s) }\end{array}$ & $\begin{array}{l}\text { Multifactorial theories } \\
\text { (including all the above) }\end{array}$ & $\begin{array}{l}\text { Multiple risk fa } \\
\text { above) }\end{array}$ & actors (including all the & $\begin{array}{l}\text { (Constantino, 2016; } \\
\text { Korbin, Coulton, } \\
\text { Lindstrom-Ufuti, \& } \\
\text { Spilsbury, 2000; Silva et al., } \\
\text { 1998) }\end{array}$ & $\begin{array}{l}\text { - Multi-agency and sectoral } \\
\text { services } \\
\text { - Multidisciplinary } \\
\text { collaborative approaches }\end{array}$ \\
\hline
\end{tabular}




\subsection{Risk-Factor Research}

Generally, there are three components to risk-factor research: estimation, evaluation, and management (Kraemer et al., 2005). While risk estimation involves attempts to identify variables associated with child abuse and neglect, risk evaluation aims to evaluate whether results from risk-estimation research can be applied in real populations and clinical settings. Following from this, risk-management research aims to assess how to manage the results from risk-estimation research (Kraemer et al., 2005). Therefore, risk-estimation research may identify malleable (modifiable) or fixed (non-modifiable) risk factors associated with child abuse and neglect, with the former able to be addressed through prevention interventions. Thus, accurate identification of both modifiable and non-modifiable risk factors is important for the early identification of families/parents with elevated risk of child abuse and neglect.

However, risk-estimation researchers operating within and adhering to particular conceptualisation frameworks (e.g., psychiatric/psychological model) may disregard broader sociological and contextual domains such as cultural and ecological factors. Thus, the approach to, and design of, prevention and intervention strategies related to child abuse and neglect may vary depending on the particular conceptualisation of risk factors and aetiological frameworks. For example, when considered a social problem, conceptual differences across societies and communities lead to the emergence of divergent forms of prevention efforts and strategies. Hence, the multifactorial conceptualisation (e.g., bio-psychosocio-cultural model) of child abuse and neglect implies that actions aimed at child abuse prevention activities require coordinated and collaborative efforts at the local, national, and international community levels.

\subsection{Effect of Child Abuse and Neglect}

Whilst there are various conceptual frameworks that attempt to analyse child abuse in family and society (e.g. psychopathology, neuropsychological, cultural, social-situational, or Foucauldian perspective of abuse as socially constructed (see Bell, 1973; DeGregorio, 2013; Lenton, 1990); child abuse and neglect cause and create "real" traumatic experiences with life-long negative impacts on various domains of physical and mental health development and functioning.

The argument for prevention efforts is further justified and strengthened by the many influential research studies indicating a "dose-response association" between child trauma, abuse, neglect and adult-onset psychopathologies. For example, numerous studies have found a strong relationship between child abuse and increase risk of developing psychotic disorders (Misiak et al., 2017), posttraumatic stress disorder (Khoury, Tang, Bradley, Cubells, \& Ressler, 2010), sexual disorders (Maniglio, 2011), mood and anxiety disorders (Heim \& Nemeroff, 2001), family violence (Şahin et al., 2010), psychopathology in psychiatric patients (Orsel, Karadağ, Kahiloğullari, \& Aktaş, 2011), borderline personality disorder (Herman, Perry, \& van der Kolk, 1989), chronic fatigue syndrome (Heim et al., 2009), substance misuse (Cuomo, Sarchiapone, Giannantonio, Mancini, \& Roy, 2008), and 
poor health-related quality of life (Weber, Jud, \& Landolt, 2016). Overall, such research implies that child abuse and neglect significantly impact the trajectory of health over the life course. At an international community level, child abuse and neglect "contributes significantly to the global burden of diseases among children and increases their predisposition to serious illnesses in adulthood" (Asnes \& Leventhal, 2009: p. 463). Hence, in theory, early preventive intervention efforts may alter and substantially reduce "abnormal" life trajectories. Currently, there are some promising efforts to end child abuse and neglect, and these are discussed in the following section.

\section{Prevention Science and Practices}

In 1883, Elbridge Gerry (1883) stated that "cruelty to children produces mental and physical disease, and the prevention of such cruelty is a matter, therefore, of grave public importance" (p. 68). To date, prevention science and practices remain central to combatting child abuse and neglect. Prevention science and practices may focus on preventing further abuse in families at "high-risk" where abuse has been identified (tertiary and secondary intervention models) or on preventing abuse or neglect from occurring in the first instance (universal/primary prevention models at community and population level) (Cabanillas, Gonzalez, \& Ortega, 1996). This classification of prevention and intervention represents a public-health approach to child abuse and neglect (Broadley \& Goddard, 2014; O'donnell, Scott, \& Stanley, 2008).

In terms of specific prevention approaches, a systematic review of eight randomised controlled trials designed to decrease child abuse in families at highrisk, found that only home visitation was an effective strategy (Levey et al., 2017). Further, an earlier systematic review-of-reviews identified 26 reviews that included 298 publications on the effectiveness of home visitation, parent education, abusive head-trauma prevention, multi-component interventions, child sexual abuse prevention, media-based interventions, and support and mutual-aid activities (Mikton \& Butchart, 2009). The results indicated that while the first four types of interventions are promising, the findings vary considerably due to methodological limitations.

A common theme across the above-mentioned reviews is that research on the effectiveness of prevention activities appear to be almost exclusively within English-speaking, high-income countries (Levey et al., 2017; Mikton \& Butchart, 2009). More specifically, "data from low- and middle-income countries are limited" (Levey et al., 2017: p. 48) and "make up only $0.6 \%$ of the total evidence base" (Mikton \& Butchart, 2009: p. 353). More broadly, child abuse and neglect research activities, appear to be concentrated in Western cultural countries (Stoltenborgh et al., 2015).

Despite the uneven distribution of published prevention studies across the globe, there appears to be universal agreement that "it shouldn't hurt to be a child", yet "how to prevent this hurt and at what cost is less clear" (Daro \& Donnelly, 2002a: p. 732). It has been argued that every country of the world "has to 
think deliberately about how it will protect its children [...] from violence, abuse, exploitation [...] as a matter of a child's fundamental rights" (Wulczyn et al., 2010: p. 5). The World report on violence and health recommends an ecological model to be used as a framework to end violence in general and child abuse and neglect in particular (Krug et al., 2002). Generally, this model emphasises that to end child abuse and neglect, it is "necessary to act across several different levels at the same time" (Krug et al., 2002: p. 1085) (see Table 2).

Similarly, collaborative efforts between international organisations (e.g., WHO, and End Violence Against Children: The Global Partnership) have contributed to the production of an evidence-based resource that "represents a select group of strategies based on the best available evidence to help countries and communities intensify their focus on prevention programmes and services" (WHO, 2016a: p. 8). These strategies include implementation and enforcement of laws; norms and values; safe environments; parent and caregiver support; income and economic strengthening; response and support services; and education and life skills (referred to as "INSPIRE") (WHO, 2016a).

Table 2. Recommended approaches to end child abuse and neglect.

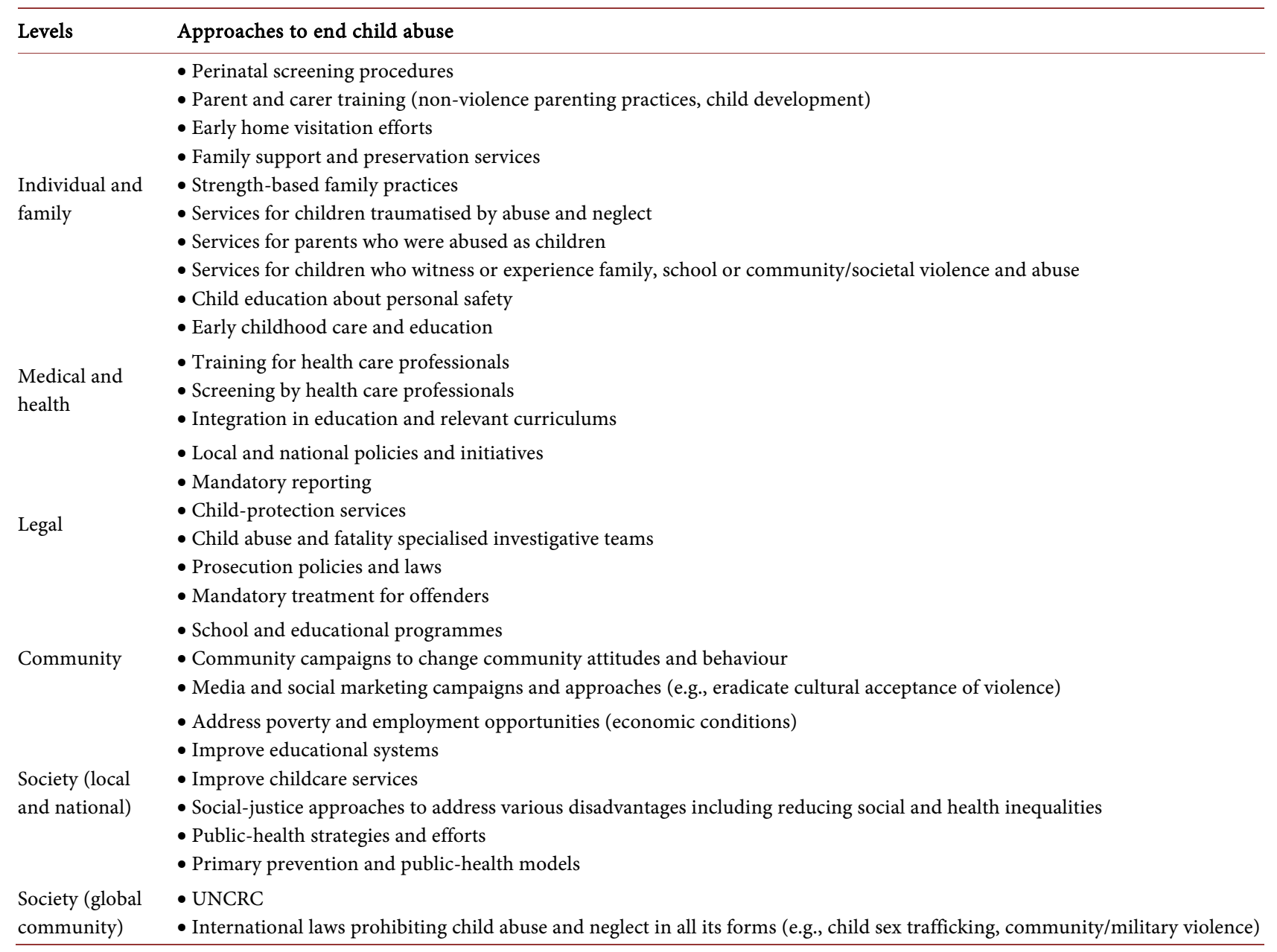

Note. Information derived from multiple sources (e.g. Asnes \& Leventhal, 2009; Barth, 2009; Bethea, 1999; Cox, Webber, \& Joachim, 2007; Donnelly, 2002; Fallon et al., 2013; Gray, Cutler, Dean, \& Kempe, 1979; Krug et al., 2002; Rosenberg \& Reppucci, 1985; WHO, 2016a). 
In general, these prevention activities are consistent with a socioecological model and social-justice framework for understanding and preventing all forms of violence (including abuse and neglect) against all children of the world. However, one of the many key challenges for systematic implementation of these strategies is the considerable social and health inequalities and substantial gaps and disparities in resources prevalent in the current global climate (Marmot, 2015).

It has been recommended that to end child abuse and neglect, each country of the world needs to adopt a national plan that includes: review and reform of local and national legislation and policies; build data collection and research capacity; culturally appropriate services; and culturally endorsed prevention practices (Hillis et al., 2016; Krug et al., 2002). However, one of the many challenges is that while in every community and society of the world there may be laws and norms that prohibit child abuse and neglect, the effectiveness of law enforcement varies across communities and societies. A lack of consistent enforcement can be attributed to factors that differ from one society to another. These issues warrant further research and investigation in reference to implementation efforts and strategies.

Further, the uptake and application of "predetermined, monolithic intervention strategies" (Daro \& Donnelly, 2002b: p. 3) may also have contributed to the failures of adequately progressing the field of prevention of child abuse and neglect across the globe. Hence, while there is a global priority on ending all forms of violence against children in general, and child abuse and neglect at the international community level (Hillis et al., 2016; WHO, 2016a), the development, implementation and evaluation of possible and specific solutions and interventions at any given local or national level are likely to be conceptualised and implemented differently across societies and cultures. Therefore, locally endorsed solutions at various levels (e.g., individual, family, community, society) could significantly reduce rates of child abuse and neglect in particular communities and societies. These strategies are likely to collectively contribute toward eradicating all forms of child abuse at the local, national, and international community levels.

\section{Child Abuse-Free Society}

Prevention of all forms of violence against children in general, and parental inflicted child abuse and neglect in particular, is a global priority that demands every country of the world to "eliminate, rather than merely reduce [...] all forms of violence against children" (Hillis et al., 2016: p. 2). However, one of the many major challenges is that child abuse and neglect do not occur in isolation within any given society. For example, it is argued that: "Gang violence is connected to bullying is connected to school violence is connected to IPV [intimate partner violence] is connected to child abuse is connected to elder abuse. It's all connected" (Deborah Prothrow-Stith, as cited in Wilkins, Tsao, Hertz, Davis, \& 
Klevens, 2014: p. 1). Thus, the international-community and global initiatives to end all forms of violence against all children of the world generally adopt socioecological and social-justice frameworks that emphasise coordinated mechanisms and organised multi-agency and multi-sectoral collaboration within and between countries of the world (Krug et al., 2002; WHO, 2016a). These collective and coordinated systematic efforts are likely to considerably contribute towards a society free of child abuse and neglect.

\section{Resilience and Adversity}

As stated earlier, child abuse and neglect exist in every society, but not in every family. In terms of families, it is very important to recognise that not all parents and caregivers who experience the well-identified adverse experiences, stressful and contributory risk factors (e.g., poverty, housing issues, mental ill-health, substance and drugs misuse) abuse and/or neglect their children. Many parents continue to adhere to the principles of "good parenting", even if they have children who present with emotional and/or behavioural difficulties or special needs (Belsky, 1984; Koenig, Barry, \& Kochanska, 2010). Many parents continue to be resilient and adaptive despite experiencing high social and health disadvantages; these domains of resiliency warrant further research and investigations utilising rigorous methodologies such as prospective and longitudinal studies.

In addition, it is well recognised that 1) there is no single growth-fostering parenting approach for promoting child safety and wellbeing (Belsky, 1984) (e.g. multidimensional model of parenting and disciplinary practices), and 2) there are culture-specific factors and variations in child-rearing practices (Raman \& Hodes, 2012). Despite these variations in disciplinary practices, including corporal punishment, harsh parenting techniques, which remain debatable within public and policy contexts (Whipple and Richey, 1997; Ben-Arieh and Haj-Yahia 2008), there is a genuine universal agreement that child abuse and neglect is not acceptable (Bross, Miyoshi, Miyoshi, \& Krugman, 2000).

As stated earlier, despite experiences of social and health disadvantages, including the ever-increasing societal trends towards "socially toxic environments" (Garbarino, 1995), in which many children of the world are not immune to adverse and traumatic experiences, there are many parents who provide the necessary safety and growth-promoting experiences for their children. Thus, it is highly essential to understand family and parental resilience and the protective factors that support families to be free of child abuse despite living in a current global system that is marked by significant social, economic, health injustice and inequalities (Marmot, 2015).

Shifting the focus from parents to children, as stated earlier, child abuse and neglect consistently predict later onset of a range of health-related issues, yet research in this area reveals exceptions (Afifi \& MacMillan, 2011; Jaffee, Caspi, Moffitt, Polo-Tomas, \& Taylor, 2007; Luthar \& Zigler, 1991; Mrazek \& Mrazek, 1987). The strong significant relationship between historical experiences of vio- 
lence in general, and abuse and neglect in particular, and current functioning is far from a "perfect" association. Not all children who experience abuse and neglect will develop any form of psychopathology or any other health-related issues. The continuity of association is subject to change, possibly due to protective factors at various levels, including those arising from the individual, family, neighbourhood, and the community.

This raises critical questions for prevention science and practices: When child abuse and neglect is not followed by adverse physical or psychological consequences, what factors are responsible? What are the protective and "naturally" occurring therapeutic factors in a child's family and community, and in broader society? What leads a child who have experienced abuse and/or neglect to develop "normally" and break the intergenerational transmission of trauma as an adult? What distinguishes children who continuously develop strong resiliency from children who experience negative consequences? While resilience "is not static; it may vary over time and across developmental phases", the question remains about what contributes to "change from resilience to no resilience and vice versa" (Afifi \& MacMillan, 2011: p. 267). Answers to these questions are likely to enhance our conceptualisation and understanding of how to promote and strengthen resiliency following adverse experiences at the individual, family, community and societal levels. These endeavours are likely to pave the path towards a child-abuse-free society.

\section{Working Together to End Child Abuse and Neglect}

So, please, can we work together towards a society free of child abuse and neglect? There is a vision and commitment at local, national, and international level to not only reduce, but to end all forms of violence against all children of the world. The adoption and endorsement of the United Nations Convention on the Rights of the Child (UNCRC) in 1989 by most of world's countries is a promising initiative. While child abuse and neglect is a global phenomenon, it is a multifactorial social and public-health problem that is likely to be conceptualised differently across cultures and societies of the world. Thus, in relation to prevention science and practices, at least in relation to the psychological sciences, it is recommended to strengthen and draw on Indigenous psychologies in various regions of the world (Allwood \& Berry, 2006) and on global psychology (Berry, 2015), which attempt to study "specificity" and "universality", respectively.

It is clear that research on child abuse and neglect and prevention science is likely to advance through a national and international collaboration of researchers who: 1) develop psychologies and social sciences related to child abuse and neglect that are locally appropriate and relevant to their sociocultural contexts (specificity); and 2) conduct comparative cross-cultural studies to understand aspects of child abuse and neglect that we all share as members of one humanity (universality). These collective and collaborative efforts are promising activities and are likely to considerably contribute to the path towards a society free of 
child abuse and neglect at the local, national, and ultimately international levels as one united community of humanity.

The WHO strongly advocates for coordinated mechanisms and working together within and between all countries of the world (Krug et al., 2002; Marmot, 2015; WHO, 2016a). However, while these collaborative efforts are promising, one of the many major challenges relate to implementation barriers and obstacles related to the current global system being marked by significant social, economic and health injustice and inequalities (Marmot, 2015).

Prevention science and practices are both research and clinical endeavours that ought to unite all child abuse and neglect researchers, practitioners, and policy makers around the world. Appropriate, locally developed, implemented and evaluated prevention initiatives and activities at various levels in any particular community, society or country have the advantage of leading towards a global network in which researchers, practitioners and policy makers can unite and speak with one voice about a general framework and standards for the prevention of child abuse and neglect. While the UNCRC has been ratified by most of the world's countries, further appropriate measures and indicators are necessary to assess prevention efforts in both national and international communities. However, the question remains about how "success" in preventing child abuse can be measured.

\section{Conclusion: Way Forward}

Many children of the world continue to experience various forms of violence, abuse, and neglect, perpetrated by societies and/or parents. This paper was written to emphasise that in the current increasingly "socially toxic environments" around the world (Garbarino, 1995; Vera \& Shin, 2006), with significant social, economic and health injustice and inequalities (Marmot, 2015), there is an urgent need to explore what parents need to provide a safe and protective family environment for their children, and what society can offer to support and empower individuals, families and communities to prevent child abuse and neglect. This paper was written with an ambitious goal and hope that prevention science and practices would unite all child abuse and neglect researchers, practitioners and policy makers around the world to ensure that working together contributes to the global impact of collective efforts to progress human welfare and contribute to safer and stronger families and futures with genuine adherence to and implementation of the principles of human rights.

\section{Conflicts of Interest}

The author declares no conflicts of interest regarding the publication of this paper.

\section{References}

Afifi, T. O., \& MacMillan, H. L. (2011). Resilience Following Child Maltreatment: A Re- 
view of Protective Factors. The Canadian Journal of Psychiatry, 56, 266-272. https://doi.org/10.1177\%2F070674371105600505

Allwood, C. M., \& Berry, J. W. (2006). Origins and Development of Indigenous Psychologies: An International Analysis. International Journal of Psychology, 41, 243-268. https://doi.org/10.1080/00207590544000013

Ammerman, R. T., Van Hasselt, V. B., \& Hersen, M. (1988). Maltreatment of Handicapped Children: A Critical Review. Journal of Family Violence, 3, 53-72. https://doi.org/10.1007/BF00994666

Asen, K., George, E., Piper, R., \& Stevens, A. (1989). A Systems Approach to Child Abuse: Management and Treatment Issues. Child Abuse and Neglect, 13, 45-57. https://doi.org/10.1016/0145-2134(89)90028-8

Asnes, A. G., \& Leventhal, J. M. (2009). The Global Burden of Child Maltreatment. In J. Ehiri (Ed.), Maternal and Child Health: Global Challenges, Programs, and Policies (pp. 463-477). Springer.

Barth, R. P. (2009). Preventing Child Abuse and Neglect with Parent Training: Evidence and Opportunities. The Future of Children, 19, 95-118. http://doi.org/10.1353/foc. 0.0031

Bell, G. (1973). Parents Who Abuse Their Children. Canadian Psychiatric Association Journal, 18, 223-228. https://doi.org/10.1177\%2F070674377301800309

Belsey, M. A. (1993). Child Abuse: Measuring a Global Problem. World Health Statistics Quarterly, 46, 69-77.

Belsky, J. (1984). The Determinants of Parenting: A Process Model. Child development, 55, 83-96. https://doi.org/10.2307/1129836

Belsky, J. (1993). Etiology of Child Maltreatment: A Developmental-Ecological Analysis. Psychological Bulletin, 114, 413-434. https://doi.apa.org/doi/10.1037/0033-2909.114.3.413

Ben-Arieh, A., \& Haj-Yahia, M. M. (2008). Corporal Punishment of Children: A MultiGenerational Perspective. Journal of Family Violence, 23, Article No. 687. https://doi.org/10.1007/s10896-008-9193-4

Berry, J. W. (2015). Global Psychology: Implications for Cross-Cultural Research and Management. Cross Cultural Management, 22, 342-355. https://doi.org/10.1108/CCM-03-2015-0031

Bethea, L. (1999). Primary Prevention of Child Abuse. American Family Physician, 59, 1577-1585.

Broadley, K., \& Goddard, C. (2014). A Public Health Approach to Child Protection: Why Data Matter. Children Australia, 40, 69-77. https://doi.org/10.1017/cha.2014.37

Bross, D., Miyoshi, T., Miyoshi, P., \& Krugman, R. (2000). World Perspectives on Child Abuse: The Fourth International Resource Book. Kempe Children's Center, University of Colorado School of Medicine.

Cabanillas, M. C., Gonzalez, J. M. M., \& Ortega, M. G. J. (1996). Child Abuse Prevention. Anuario de Psicología Jurídica, 1, 104-118.

Chess, S., \& Thomas, A. (1991). Temperament and the Concept of Goodness of Fit. In J. Strelau, \& A. Angleitner (Eds.), Perspectives on Individual Differences. Explorations in Temperament: International Perspectives on Theory and Measurement (pp. 15-28). Springer.

Cicchetti, D., \& Lynch, M. (1993). Toward an Ecological/Transactional Model of Community Violence and Child Maltreatment: Consequences for Children's Development. Psychiatry, 56, 96-118. https://doi.org/10.1080/00332747.1993.11024624 
Constantino, J. N. (2016). Child Maltreatment Prevention and the Scope of Child and Adolescent Psychiatry. Child and Adolescent Psychiatric Clinics of North America, 25, 157-165. https://doi.org/10.1016/j.chc.2015.11.003

Cox, J. M. D. C., Webber, B. J. D., \& Joachim, G. D. C. (2007). A Community Program to Fight Child Abuse: the Fort Wayne Children's Foundation and Kids' Law. Journal of Manipulative \& Physiological Therapeutics, 30, 607-613. https://doi.org/10.1016/j.jmpt.2007.08.001

Cuomo, C., Sarchiapone, M., Giannantonio, M. D., Mancini, M., \& Roy, A. (2008). Aggression, Impulsivity, Personality Traits, and Childhood Trauma of Prisoners with Substance Abuse and Addiction. The American Journal of Drug and Alcohol Abuse, 34, 339-345. https://doi.org/10.1080/00952990802010884

Daghestani, A. N. (1997). al-Razi (Rhazes), 865-925. American Journal of Psychiatry, 154, 1602-1602. https://doi.org/10.1176/ajp.154.11.1602

Daro, D., \& Donnelly, A. C. (2002a). Charting the Waves of Prevention: Two Steps Forward, One Step Back. Child Abuse and Neglect, 26, 731-742. https://doi.org/10.1016/S0145-2134(02)00344-7

Daro, D., \& Donnelly, A. C. (2002b). Child Abuse Prevention: Accomplishments and Challenges. The APSAC Handbook on Child Maltreatment, 2, 1-24.

Daro, D., Downs, B., Keeton, K., McCurdy, K., Beard, S., \& Keaton, A. (1992). World Perspectives on Child Abuse: An International Resource Book. National Committee for the Prevention of Child Abuse.

DeGregorio, L. J. (2013). Intergenerational Transmission of Abuse: Implications for Parenting Interventions from a Neuropsychological Perspective. Traumatology, 19, 158-166. https://doi.apa.org/doi/10.1177/1534765612457219

Donnelly, A. C. (2002). An International Movement to End Child Abuse: The Story of ISPCAN. International Society for Prevention of Child Abuse and Neglect (ISPCAN).

Drake, B., \& Pandey, S. (1996). Understanding the Relationship between Neighborhood Poverty and Specific Types of Child Maltreatment. Child Abuse \& Neglect, 20, 1003 1018. https://doi.org/10.1016/0145-2134(96)00091-9

Fairburn, A., \& Hunt, A. (1964). Caffey's “Third Syndrome”-A Critical Evaluation. Medicine, Science and the Law, 4, 123-126. https://doi.org/10.1177\%2F002580246400400212

Fallon, B., Ma, J., Allan, K., Pillhofer, M., Trocme, N., \& Jud, A. (2013). Opportunities for Prevention and Intervention with Young Children: Lessons from the Canadian Incidence Study of Reported Child Abuse and Neglect. Child and Adolescent Psychiatry and Mental Health, 7, Article No. 4.

Ferguson, T. (1955). Cruelty to Children. British Medical Journal, 2, Article No. 184. https://doi.org/10.1136/bmj.2.4932.184

Fitch, F. J. M. S., \& Papantonio, A. M. A. (1983). Men Who Batter: Some Pertinent Characteristics. Journal of Nervous \& Mental Disease, 171, 190-192. https://doi.org/10.1097/00005053-198303000-00011

Fleming, G. (1967). Cruelty to Children. British Medical Journal, 2, Article No. 421. https://doi.org/10.1136/bmj.2.5549.421

Friedrich, W. N., \& Wheeler, K. K. (1982). The Abusing Parent Revisited: A Decade of Psychological Research. Journal of Nervous and Mental Disease, 170, 577-587. https://doi.org/10.1097/00005053-198210000-00001

Garbarino, J. (1995). Raising Children in a Socially Toxic Environment. Jossey-Bass Inc.

Gerry, E. T. (1883). Cruelty to Children. The North American Review, 137, 68-75.

Gil, D. G. (1969). Physical Abuse of Children: Findings and Implications of a Nationwide 
Survey. Pediatrics, 44, 857-864.

Gil, D. G. (1970). Violence against Children: Physical Child Abuse in the United States (Vol. 6). Harvard University Press.

Gray, J. D., Cutler, C. A., Dean, J. G., \& Kempe, C. H. (1979). Prediction and Prevention of Child Abuse and Neglect. Journal of Social Issues, 35, 127-139. https://doi.org/10.1111/j.1540-4560.1979.tb00805.x

Griffiths, D. L., \& Moynihan, F. (1963). Multiple Epiphysial Injuries in Babies ("Battered Baby" Syndrome). British Medical Journal, 2, 1558-1561. https://doi.org/10.1136/bmj.2.5372.1558

Heim, C., \& Nemeroff, C. B. (2001). The Role of Childhood Trauma in the Neurobiology of Mood and Anxiety Disorders: Preclinical and Clinical Studies. Biological Psychiatry, 49, 1023-1039. https://doi.org/10.1016/S0006-3223(01)01157-X

Heim, C., Nater, U. M., Maloney, E., Boneva, R., Jones, J. F., \& Reeves, W. C. (2009). Childhood Trauma and Risk for Chronic Fatigue Syndrome: Association with Neuroendocrine Dysfunction. Archives of General Psychiatry, 66, 72-80.

https://doi.org/10.1001/archgenpsychiatry.2008.508

Herman, J. L., Perry, C., \& van der Kolk, B. A. (1989). Childhood Trauma in Borderline Personality Disorder. American Journal of Psychiatry, 146, 490-495. https://doi.org/10.1176/ajp.146.4.490

Hillis, S., Mercy, J., Amobi, A., \& Kress, H. (2016). Global Prevalence of Past-Year Violence against Children: A Systematic Review and Minimum Estimates. Pediatrics, 137, e20154079. https://doi.org/10.1542/peds.2015-4079

Jaffee, S. R., Caspi, A., Moffitt, T. E., Polo-Tomas, M., \& Taylor, A. (2007). Individual, Family, and Neighborhood Factors Distinguish Resilient from Non-Resilient Maltreated Children: A Cumulative Stressors Model. Child Abuse and Neglect, 31, 231-253. https://doi.org/10.1016/j.chiabu.2006.03.011

Kapitanoff, S. H., Lutzker, J. R., \& Bigelow, K. M. (2000). The Relation between Child Disabilities and Child Abuse. Aggression and Violent Behavior, 5, 227-244. https://doi.org/10.1016/S1359-1789(98)00040-8

Kempe, C. H., Silverman, F. N., Steele, B. F., Droegemueller, W., \& Silver, H. K. (1962). The Battered-Child Syndrome. JAMA, 181, 17-24. https://doi.org/10.1001/jama.1962.03050270019004

Khoury, L., Tang, Y. L., Bradley, B., Cubells, J. F., \& Ressler, K. J. (2010). Substance Use, Childhood Traumatic Experience, and Posttraumatic Stress Disorder in an Urban Civilian Population. Depression and Anxiety, 27, 1077-1086. https://doi.org/10.1002/da.20751

Knight, B. (1986). The History of Child Abuse. Forensic Science International, 30, 135-141. https://doi.org/10.1016/0379-0738(86)90008-3

Koenen, M. A., \& Thompson Jr., J. W. (2008). Filicide: Historical Review and Prevention of Child Death by Parent. Infant Mental Health Journal, 29, 61-75. https://doi.org/10.1002/imhj.20166

Koenig, J. L., Barry, R. A., \& Kochanska, G. (2010). Rearing Difficult Children: Parents' Personality and Children's Proneness to Anger as Predictors of Future Parenting. Parenting: Science and Practice, 10, 258-273. https://doi.org/10.1080/15295192.2010.492038

Korbin, J. E., Coulton, C. J., Lindstrom-Ufuti, H., \& Spilsbury, J. (2000). Neighborhood Views on the Definition and Etiology of Child Maltreatment. Child Abuse \& Neglect, 24, 1509-1527. https://doi.org/10.1016/S0145-2134(00)00206-4 
Kraemer, H. C., Lowe, K. K., \& Kupfer, D. J. (2005). To Your Health: How to Understand What Research Tells Us about Risk. Oxford University Press.

Krug, E. G., Mercy, J. A., Dahlberg, L. L., \& Zwi, A. B. (2002). The World Report on Violence and Health. The Lancet, 360, 1083-1088.

https://doi.org/10.1016/S0140-6736(02)11133-0

Lenton, R. (1990). Techniques of Child Discipline and Abuse by Parents. Canadian Review of Sociology/Revue canadienne de sociologie, 27, 157-185. https://doi.org/10.1111/j.1755-618X.1990.tb00449.x

Levey, E. J., Gelaye, B., Bain, P., Rondon, M. B., Borba, C. P., Henderson, D. C., \& Williams, M. A. (2017). A Systematic Review of Randomized Controlled Trials of Interventions Designed to Decrease Child Abuse in High-Risk Families. Child Abuse \& Neglect, 65, 48-57. https://doi.org/10.1016/j.chiabu.2017.01.004

Luthar, S. S., \& Zigler, E. (1991). Vulnerability and Competence: A Review of Research on resilience in Childhood. American Journal of Orthopsychiatry, 61, 6-22. https://doi.apa.org/doi/10.1037/h0079218

Lutzker, J. R., \& Newman, M. R. (1986). Child Abuse and Neglect: Community Problem, Community Solutions. Education and Treatment of Children, 9, 344-354.

Lynch, M. A. (1985). Child Abuse before Kempe: An Historical Literature Review. Child Abuse \& Neglect, 9, 7-15. https://doi.org/10.1016/0145-2134(85)90086-9

Maniglio, R. (2011). The Role of Childhood Trauma, Psychological Problems, and Coping in the Development of Deviant Sexual Fantasies in Sexual Offenders. Clinical Psychology Review, 31, 748-756. https://doi.org/10.1016/j.cpr.2011.03.003

Marmot, M. (2015). The Health Gap: The Challenge of an Unequal World. The Lancet, 386, 2442-2444. https://doi.org/10.1016/S0140-6736(15)00150-6

Marten, J. (2018). The History of Childhood: A Very Short Introduction. Oxford University Press. https://doi.org/10.1093/actrade/9780190681388.001.0001

Mikton, C., \& Butchart, A. (2009). Child Maltreatment Prevention: A Systematic Review of Reviews. Bulletin of the World Health Organization, 87, 353-361. https://doi.org/10.2471/BLT.08.057075

Milowe, I. D., Lourie, R. S., \& Parrott, R. (1964). The Child's Role in the Battered Child Syndrome. The Journal of Pediatrics, 65, 1079-1081. https://doi.org/10.1016/S0022-3476(64)80071-8

Misiak, B., Krefft, M., Bielawski, T., Moustafa, A. A., Sąsiadek, M. M., \& Frydecka, D. (2017). Toward a Unified Theory of Childhood Trauma and Psychosis: A Comprehensive Review of Epidemiological, Clinical, Neuropsychological and Biological Findings. Neuroscience \& Biobehavioral Reviews, 75, 393-406. https://doi.org/10.1016/j.neubiorev.2017.02.015

Modanlou, H. D. (2015). Medical Care of Children during the Golden Age of Islamic Medicine. Archives of Iranian Medicine, 18, 263-265.

Morrow, V. (2011). Understanding Children and Childhood(2nd ed.). Centre for Children and Young People Background Briefing Series, No. 1, Centre for Children and Young People, Southern Cross University.

Mrazek, P. J., \& Mrazek, D. A. (1987). Resilience in Child Maltreatment Victims: A Conceptual Exploration. Child Abuse \& Neglect, 11, 357-366.

O'donnell, M., Scott, D., \& Stanley, F. (2008). Child Abuse and Neglect-Is It Time for a Public Health Approach? Australian and New Zealand Journal of Public Health, 32, 325-330.

Orsel, S., Karadağ, H., Kahiloğullari, A. K., \& Aktaş, E. A. (2011). The Frequency of 
Childhood Trauma and Relationship with Psychopathology in Psychiatric Patients. Anatolian Journal of Psychiatry, 12, 130-136.

Pfohl, S. J. (1977). The "Discovery" of Child Abuse. Social Problems, 24, 310-323. https://doi.org/10.2307/800083

Prevoo, M. J., Stoltenborgh, M., Alink, L. R., Bakermans-Kranenburg, M. J., \& IJzendoorn, M. H. (2017). Methodological Moderators in Prevalence Studies on Child Maltreatment: Review of a Series of Meta-Analyses. Child Abuse Review, 26, 141-157. https://doi.org/10.1002/car.2433

Qiao, D., \& Chan, Y.-C. (2005). Child abuse in China: a Yet-to-Be-Acknowledged 'Social Problem' in the Chinese Mainland. Child \& Family Social Work, 10, 21-27. https://doi.org/10.1111/j.1365-2206.2005.00347.x

Radbill, S. X. (1971). The First Treatise on Pediatrics. American Journal of Diseases of children, 122, 369-371. https://doi.org/10.1001/archpedi.1971.02110050039001

Raman, S., \& Hodes, D. (2012). Cultural Issues in Child Maltreatment. Journal of Paediatrics and Child Health, 48, 30-37. https://doi.org/10.1111/j.1440-1754.2011.02184.x

Rosenberg, M. S., \& Reppucci, N. D. (1985). Primary Prevention of Child Abuse. Journal of Consulting and Clinical Psychology, 53, 576-585. https://doi.apa.org/doi/10.1037/0022-006X.53.5.576

Şahin, N. H., Timur, S., Ergin, A. B., Taşpinar, A., Balkaya, N. A., \& Çubukçu, S. (2010). Childhood Trauma, Type of Marriage and Self-Esteem as Correlates of Domestic Violence in Married Women in Turkey. Journal of Family Violence, 25, 661-668. https://doi.org/10.1007/s10896-010-9325-5

Silva, J. A., Leong, G. B., Dassori, A., Ferrari, M. M., Weinstock, R., \& Yamamoto, J. (1998). A Comprehensive Typology for the Biopsychosociocultural Evaluation of ChildKilling Behavior. Journal of Forensic Science, 43, 1112-1118. https://doi.org/10.1520/JFS14371J

Slack, K. S., Holl, J. L., McDaniel, M., Yoo, J., \& Bolger, K. (2004). Understanding the Risks of Child Neglect: An Exploration of Poverty and Parenting Characteristics. Child Maltreatment, 9, 395-408. https://doi.org/10.1177\%2F1077559504269193

Stoltenborgh, M., Bakermans-Kranenburg, M. J., Alink, L. R. A., \& van Ijzendoorn, M. H. (2015). The Prevalence of Child Maltreatment across the Globe: Review of a Series of Meta-Analyses. Child Abuse Review, 24, 37-50. https://doi.org/10.1002/car.2353

Thomas Jr., M. P. (1971). Child Abuse and Neglect Part I-Historical Overview, Legal Matrix, and Social Perspectives. North Carolina Law Review, 50, 293-349.

Tubbs, R. S., Shoja, M. M., Loukas, M., \& Oakes, W. J. (2007). Abubakr Muhammad Ibn Zakaria Razi, Rhazes (865-925 AD). Child s Nervous System, 23, 1225-1226. https://doi.org/10.1007/s00381-007-0368-8

Ullmann, E., \& Hilweg, W. (1999). Childhood and Trauma: Separation, Abuse, War. Ashgate Publishing Company.

UNICEF (1999). United Nations Convention on the Rights of the Child, 1989. Geneva: UNICEF.

Vera, E. M., \& Shin, R. Q. (2006). Promoting Strengths in a Socially Toxic World: Supporting Resiliency with Systemic Interventions. The Counseling Psychologist, 34, 80-89. https://doi.org/10.1177\%2F0011000005282365

Weber, S., Jud, A., \& Landolt, M. A. (2016). Quality of Life in Maltreated Children and Adult Survivors of Child Maltreatment: A Systematic Review. Quality of Life Research, 25, 237-255. https://doi.org/10.1007/s11136-015-1085-5

Whipple, E. E., \& Richey, C. A. (1997). Crossing the Line from Physical Discipline to 
Child Abuse: How Much Is Too Much? Child Abuse \& Neglect, 21, 431-444. https://doi.org/10.1016/S0145-2134(97)00004-5

White, A. P. R., Benedict, M. I., Wulff, L., \& Kelley, M. (1987). Physical Disabilities as a Risk Factor for Child Maltreatment: A Selected Review. American Journal of Orthopsychiatry, 57, 93-101. https://doi.apa.org/doi/10.1111/j.1939-0025.1987.tb03513.x

WHO [World Health Organization] (2016a). INSPIRE: Seven Strategies for Ending Violence against Children (No. 9241565357). World Health Organization.

WHO [World Health Organization] (2016b). International Society for Prevention of Child Abuse and Neglect (ISPCAN) (2006). Preventing Child Maltreatment: A Guide to Taking Action and Generating Evidence. World Health Organization.

Wilkins, N., Tsao, B., Hertz, M. F., Davis, R., \& Klevens, J. (2014). Connecting the Dots: An Overview of the Links among Multiple Forms of Violence.

Wolock, I. (1984). Child Maltreatment as a Social Problem: The Neglect of Neglect. American Journal of Orthopsychiatry, 54, 530-543. https://doi.apa.org/doi/10.1111/j.1939-0025.1984.tb01524.x

Wulczyn, F., Daro, D., Fluke, J., Feldman, S., Glodek, C., \& Lifanda, K. (2010). Adapting a Systems Approach to Child Protection: Key Concepts and Considerations. United Nations International Children's Emergency Fund. 